\title{
Identification and Risk Analysis of Mozarella Cheese Production Process
}

\author{
Farras Tsany ${ }^{1}$, Imam Santoso $^{\left.\mathbf{1}^{*}\right)}$, Dhita Morita Ikasari ${ }^{1}$ \\ Agroindustrial Technology Department, Faculty of Agricultural Technology, \\ Universitas Brawijaya \\ Jl. Veteran, Malang 65145 \\ *)Correspondence Author email : imamsantoso@ub.ac.id
}

\begin{abstract}
Mozzarella cheese is a food which is very risky to the growth of microorganisms since it has high water content by $54.1 \%$. One way to overcome that problem is to identify and analyze the risks found in the production process of mozzarella cheese. Therefore, the researchers examined the identification and risk analysis of mozzarella cheese production process by conducting a case study in CV XYZ. The methods used were Failure Mode and Effect Analysis (FMEA) and Fault Tree Analysis (FTA). The results revealed that there were 11 risks from 8 steps of the production process. Of the 11 risks, the risks which were included in the critical risks were the risk of contamination during the curd clotting process, low-quality of milk, severe stretcher machine damage, and overly acidic cheese taste. The result of quantitative analysis of FTA indicated that the risk probability during mozzarella cheese production process was 0.110 or the risk was $11 \%$. The probability with the highest value was the probability of contamination risk during the curd clotting process by 0.095. It indicated that contamination during the curd clotting process was the most probable risk in the future. The proposed recommendations for improvement are devising Standard Operating Procedures (SOPs) and Sanitation Standard Operating Procedures (SSOP) based on the company's condition and it should be implemented properly. Then, improving communication with suppliers is also needed so that the company will always get high quality raw materials.
\end{abstract}

Keywords: Qualitative Analysis, Quantitative Analysis, Dairy Product, Failure Mode and Effect Analysis, Fault Tree Analysis

\section{INTRODUCTION}

Indonesian people nowadays needs a noutricious food. It can be seen from the growing demand for milk commodities and the increasing national demand for milk. People awareness of milk needs contributes to the development of dairy products in Indonesia such as pasteurized milk, yogurt, cheese, kefir and butter for daily consumption.

Cheese is a well-known food product which processed from the clumping or coagulation of milk proteins. Cheese can be classified into four types namely very hard cheese, hard cheese, semi-soft cheese and soft cheese [1] [2].
Of the various types of cheese, the most widely known is soft cheese in the form of Cheddar and Mozzarella. Mozzarella cheese is a soft cheese which is not fully cooked or referred to fresh cheese. The characteristics of mozzarella cheese are elastic, stringy, and soft [3][4]. Mozzarella cheese contains $19.4 \%$ protein, $21.6 \%$ fat, and $2.20 \%$ carbohydrate. Cheese also has the high water content at $54.1 \%$. Thus Mozarella cheese is very risky to the growth of microorganisms [5] [6]. Poisoning cases are likely from the consumption of food containing toxins produced by Clostridium botulinum spore-forming bacteria and poisoning caused by Staphylococcus aureus bacteria that can grow in protein-containing foods such as sausage and cheese [7] [8]. 
Cases of poisoning or illnesses caused by consuming food contaminated by pathogenic microbes are commonly found [9]. Therefore, considering the risks that may occur in the process of cheese production is needed to prevent the contamination. One way that can be done is to identify and analyze the risks contained in the production process.

Nowadays Milk Processing Industry (IPS) in Indonesia that produces cheese products begins to emerge, ranging from home industries to companies. CVXYZ is one of IPS located in Batu city which produces or processes cow milk into the final product in the form of yoghurt and cheese. The result of cheese product is categorized as soft cheese especially Mozzarella. In running the production process of mozzarella cheese, $\mathrm{CV}$ $\mathrm{XYZ}$ also faces some risks such as the possibility of defective packaging during packing process, less stretchy mozzarella and more.

Based on those problems, it is necessary to analyze any risk that occurs and its impact. During this time, research has not been discussed about the risks during the process of cheese production in CV XYZ. The problems can be solved by employing an appropriate method. The causes of failure mode and its effect at each step of the production process can be identified by using Failure Mode and Effect Analysis (FMEA). Then, Fault Tree Analysis (FTA) can be employed to find out the cause of the problem at each stage of production process. Those two methods are used because it has some advantages.

Failure Mode and Effect Analysis (FMEA) can give suggestions for improvement in production process which has high failure rate, while Fault Tree Analysis (FTA) can analyze system failures and look for aspects of the system involved in the main failure [10]. Fault Tree Analysis (FTA) is a powerful and computationally efficient technique for analyzing and predicting reliability and security system [11]. FMEA is also described in common terms which are universally understood by people with technical limitations and / or system training [12].

\section{RESEARCH METHOD}

This research was a descriptive research since it analyzed the facts of the risks during the production process and attempted to give recommendations for improvement in order to handle the risks occurred in CV XYZ. The data were obtained from the observation, interview and questionnaire. Then it was analyzed by using Failure Mode and Effect Analysis (FMEA) and Fault Tree Analysis (FTA). The questionnaires involved in this study were open-ended questionnaire and questionnaire to determine the weight criteria of severity, occurrence and detection. The open-ended questionnaire consisted of some questions that gave the respondents chances to answer or respond to the questionnaire. The second questionnaire was used to determine which level of risk had the highest impact and effect as well as the frequency and detection of possible risks. The selection of respondents was based on following considerations:

1. The respondent was related to the production process of mozzarella cheese.

2. The respondent was an experienced employee.

\section{RESULTS AND DISCUSSION}

\section{Potential Risks}

Potential risks in the production process of mozzarella cheese were obtained from the result of interview and questionnaire from Production Manager and Department of Personnel. Risk tracking was divided based on the risk at each step of production process which consisted of 8 steps. Risks that have occurred and possible future risks in CV XYZ at each step of the production process can be seen in Table 2 . 
Table 1. Risks in Production Process of Mozzarella Cheese

\begin{tabular}{|c|c|c|}
\hline No. & Step in Production Process & Risk \\
\hline 1. & $\begin{array}{l}\text { Machinery and equipment } \\
\text { preparation }\end{array}$ & Contamination from sanitary materials \\
\hline \multirow[t]{2}{*}{2.} & \multirow[t]{2}{*}{ Raw material provision } & $\begin{array}{l}\text { Contamination during milk flowing from tube } \\
\text { to cheese vat }\end{array}$ \\
\hline & & Low-quality milk \\
\hline 3. & Milk heating process & The desired temperature was not reached \\
\hline \multirow[t]{2}{*}{4.} & \multirow{2}{*}{$\begin{array}{l}\text { Citric acid and enzyme } \\
\text { addition }\end{array}$} & Curd clotting was not maximal \\
\hline & & Contamination during clotting process \\
\hline 5. & Curd cutting & The resulting curd texture was too hard \\
\hline 6. & Mixing & Contaminants entry \\
\hline \multirow[t]{2}{*}{7.} & \multirow[t]{2}{*}{ Stretching } & Severe damage of stretcher machine \\
\hline & & Overly acidic cheese product \\
\hline 8. & Packaging & Inefficiency of secondary packaging usage \\
\hline
\end{tabular}

\section{Risk Identification}

Risk identification was performed by interviewing and distributing questionnaires that could serve as a risk statement that would occur in the future. Risk identification could reveal the source or cause and impact of each risk. The risk variables were established based on the production process steps of mozzarella cheese. There were 11 risks from the overall variables that existed in the production process of mozzarella cheese. All identified risks would be sought for its cause and impact through Failure Mode Effect and Analysis (FMEA) method. The FMEA method was started by creating a risk identification table using FMEA method. It can be seen in Table 2 .

Table 2. Failure Mode and Effect Analysis of Risks in Mozzarella Cheese Production Process

\begin{tabular}{|c|c|c|c|c|}
\hline Subject & Possible Effect & Possible Mode & $\begin{array}{c}\text { Performed } \\
\text { Control } \\
\end{array}$ & $\begin{array}{c}\text { Detection } \\
\text { Method }\end{array}$ \\
\hline \multicolumn{5}{|c|}{ Machinery and Equipment Preparation: } \\
\hline $\begin{array}{l}\text { Contamination of } \\
\text { sanitary materials }\end{array}$ & $\begin{array}{l}\text { Decreasing the } \\
\text { quality of cheese } \\
\text { product }\end{array}$ & $\begin{array}{l}\text { Negligent worker } \\
\text { while sanitizing } \\
\text { machinery and } \\
\text { equipment }\end{array}$ & $\begin{array}{l}\text { Rinsing with hot } \\
\text { and cold water }\end{array}$ & Visual \\
\hline \multicolumn{5}{|c|}{ Raw Material Provision: } \\
\hline $\begin{array}{l}\text { Contamination } \\
\text { during milk } \\
\text { flowing from tube } \\
\text { to cheese vat }\end{array}$ & $\begin{array}{l}\text { Decreasing the } \\
\text { quality of raw } \\
\text { materials }\end{array}$ & $\begin{array}{l}\text { Flowing milk in } \\
\text { open tube } \\
\text { condition }\end{array}$ & $\begin{array}{l}\text { Sanitizing the } \\
\text { room properly }\end{array}$ & Visual \\
\hline $\begin{array}{l}\text { Low-quality fresh } \\
\text { milk }\end{array}$ & $\begin{array}{l}\text { Decreasing the } \\
\text { quality of cheese } \\
\text { products }\end{array}$ & $\begin{array}{l}\text { Negligence of } \\
\text { quality control } \\
\text { suppliers }\end{array}$ & $\begin{array}{l}\text { Improving } \\
\text { communication }\end{array}$ & Visual \\
\hline \multicolumn{5}{|c|}{ Milk Heating Process: } \\
\hline $\begin{array}{l}\text { Inappropriate } \\
\text { temperature }\end{array}$ & $\begin{array}{l}\text { Pathogenic } \\
\text { microorganisms } \\
\text { still existed }\end{array}$ & $\begin{array}{l}\text { Negligent worker } \\
\text { while checking the } \\
\text { temperature }\end{array}$ & $\begin{array}{l}\text { Regular } \\
\text { temperature } \\
\text { control }\end{array}$ & Visual \\
\hline
\end{tabular}

Citric Acid And Enzyme Addition 


\begin{tabular}{|c|c|c|c|c|}
\hline Subject & Possible Effect & Possible Mode & $\begin{array}{l}\text { Performed } \\
\text { Control }\end{array}$ & $\begin{array}{c}\text { Detection } \\
\text { Method }\end{array}$ \\
\hline $\begin{array}{l}\text { Curd clotting was } \\
\text { not maximal }\end{array}$ & $\begin{array}{l}\text { Mushy curd } \\
\text { texture }\end{array}$ & $\begin{array}{l}\text { Error in } \\
\text { ingredients } \\
\text { addition }\end{array}$ & $\begin{array}{l}\text { Controlling } \\
\text { ingredients } \\
\text { addition }\end{array}$ & Visual \\
\hline \multicolumn{5}{|c|}{ Citric Acid And Enzyme Addition: } \\
\hline $\begin{array}{c}\text { Contamination } \\
\text { during clotting } \\
\text { process }\end{array}$ & $\begin{array}{l}\text { Discontinuity in } \\
\text { process }\end{array}$ & $\begin{array}{c}\text { Frequently opened } \\
\text { and closed the } \\
\text { Cheese vat } \\
\text { machine }\end{array}$ & $\begin{array}{l}\text { Checking the } \\
\text { room and workers } \\
\text { sanitation }\end{array}$ & Visual \\
\hline \multicolumn{5}{|l|}{ Curd Cutting: } \\
\hline $\begin{array}{c}\text { The resulting curd } \\
\text { texture was too } \\
\text { hard }\end{array}$ & $\begin{array}{l}\text { Interrupted mixing } \\
\text { process }\end{array}$ & $\begin{array}{l}\text { Curd and whey } \\
\text { separation process } \\
\text { took a long time }\end{array}$ & $\begin{array}{l}\text { Adding whey } \\
\text { during mixing } \\
\text { process }\end{array}$ & Visual \\
\hline \multicolumn{5}{|l|}{ Mixing: } \\
\hline $\begin{array}{l}\text { Contaminants } \\
\text { entry }\end{array}$ & $\begin{array}{l}\text { Decreasing } \\
\text { products quality }\end{array}$ & $\begin{array}{l}\text { Negligent worker } \\
\text { while sanitizing } \\
\text { the room }\end{array}$ & $\begin{array}{c}\text { Regular } \\
\text { supervision } \\
\text { during process }\end{array}$ & Visual \\
\hline \multicolumn{5}{|l|}{ Stretching: } \\
\hline $\begin{array}{l}\text { Severe damage of } \\
\text { stretcher machine }\end{array}$ & $\begin{array}{l}\text { Production } \\
\text { process delay }\end{array}$ & $\begin{array}{l}\text { Undetected part of } \\
\text { the damaged } \\
\text { machine }\end{array}$ & $\begin{array}{l}\text { Replacing the } \\
\text { damage part of } \\
\text { the machine }\end{array}$ & Visual \\
\hline $\begin{array}{l}\text { Overly acidic } \\
\text { cheese product }\end{array}$ & Low quality cheese & $\begin{array}{l}\text { Stretching process } \\
\text { took a long time }\end{array}$ & $\begin{array}{l}\text { Selling cheese } \\
\text { products cheaply }\end{array}$ & Visual \\
\hline $\begin{array}{l}\text { Inefficiency of } \\
\text { secondary } \\
\text { packaging usage }\end{array}$ & $\begin{array}{l}\text { Packaging cost } \\
\text { increase }\end{array}$ & Exhausted workers & $\begin{array}{l}\text { Changing the } \\
\text { package }\end{array}$ & Visual \\
\hline
\end{tabular}

\section{FMEA Analysis}

The first step of risk analysis was performed by assessing the SOD at each risk in order to obtain the RPN value and determine the critical risk. The severity, occurrence and detection values were derived from the average values given from each respondent which could be seen in Table 4. The average calculation of both respondents was done by using the geometric mean because the data used indicated the preferences of a group of people. The risk that had the highest RPN value was the risk at the step of citric acid and enzyme addition; that was the risk of contamination during the clotting process indicating RPN value of 24. Meanwhile, the risk that had the lowest RPN value was the risk in the preparation step of machinery and equipment and at the step of milk heating process indicating RPN value of 1 for each risk. The RPN value was obtained from SOD multiplication product that was averaged from both respondents. Based on the risk list, five risks with the highest RPN value were considered as critical risks in the production process of mozzarella cheese. Critical risk determination was based on risks that had RPN value in excess of the critical value. The critical value was obtained through the calculation of the ratio of total RPN value divided by the number of risks. A risk is categorized as a critical risk if the RPN value is above the critical value [13]. Those risks included the risk of contamination during the clotting process, low milk quality, severe damage of stretcher machine, and overly acidic cheese taste as well as the risk of contamination when flowing milk from the tube to cheese vat. 
Table 3. SOD Risk Value in Production Process of Mozzarella Cheese

\begin{tabular}{|c|c|c|c|c|c|}
\hline Step of Process & Risk & S & 0 & $\mathrm{D}$ & RPN \\
\hline $\begin{array}{l}\text { Machinery and equip- } \\
\text { ment preparation }\end{array}$ & Contamination from sanitary materials & 1 & 1 & 1 & 1 \\
\hline \multirow{2}{*}{$\begin{array}{l}\text { Raw Material } \\
\text { Provision }\end{array}$} & $\begin{array}{l}\text { Contamination during milk flowing } \\
\text { from tube to cheese vat }\end{array}$ & 2 & 2 & 2 & 8 \\
\hline & Low-quality milk & 3 & 2 & 2.44 & 14.64 \\
\hline Milk heating process & $\begin{array}{l}\text { The desired temperature was not } \\
\text { reached }\end{array}$ & 1 & 1 & 1 & 1 \\
\hline \multirow{2}{*}{$\begin{array}{l}\text { Citric acid and enzyme } \\
\text { addition }\end{array}$} & Curd clotting was not maximal & 1.41 & 1 & 1 & 1,41 \\
\hline & Contamination during clotting process & 4 & 2 & 3 & 24 \\
\hline Curd cutting & The resulting curd texture was too hard & 3 & 2.44 & 1 & 7.32 \\
\hline Mixing & $\begin{array}{l}\text { Contaminants entry during mixing } \\
\text { process }\end{array}$ & 1.41 & 1 & 1 & 1.41 \\
\hline \multirow{2}{*}{ Stretching } & Severe damage of stretcher machine & 3 & 1 & 4 & 12 \\
\hline & Overly acidic cheese product & 4 & 1 & 3 & 12 \\
\hline \multirow[t]{3}{*}{ Packaging } & Inefficiency packaging & 1 & 4.4 & 1 & 4.4 \\
\hline & Total of RPN & & & & 87.18 \\
\hline & Critical Value & & & & 7.9 \\
\hline
\end{tabular}

\section{FTA Analysis}

The risk analysis at the second step was creating a Fault Tree chart for the critical risks obtained from this study. The Fault Tree Analysis (FTA) method could identify the cause of risk relationships in more detail. The Fault Tree chart created in this study was a risk chart that once occurred in CV XYZ.

\section{Risk of Contamination during Curd Clotting Process}

FTA contamination during curd clotting process had 7 basic events in it and 9 intermediate events. After basic event was known then the minimal cut set could be searched because the minimal cut set was determined based on the FTA chart. The chart can be seen in Figure 1.
From the result of boolean algebra, it could be obtained 3 single minimum cut sets and 2 double minimum cut sets which were the causes of the top event. Based on the qualitative analysis that was done, the quantitative analysis could be performed by calculating the risk probability of each basic event. The probability was calculated based on the frequency of occurrence of risk in basic event compared with the frequency of production process implementation during August 2015-August 2016 specifically 188 times. The calculation of probability analysis was based on the equations obtained from the qualitative analysis. Quantitative analysis of the contamination risk during the curd clotting process can be seen in Table 4.

Table 4 Probability of Basic Event Failure at Contamination Risk during Curd Clotting Process

\begin{tabular}{clcc}
\hline Symbol & \multicolumn{1}{c}{ Basic Event } & Risk Frequency & Risk Probability \\
\hline C1 & Sick employee & 8 & 0.043 \\
C2 & Not optimal quality test & 1 & 0.005 \\
C3 & Too many visitors & 1 & 0.005 \\
C4 & Visitors did not wear sanitary & 1 & 0.005 \\
C5 & Supplies & 1 & 0.005 \\
C6 & Less supervision & 4 & 0.021
\end{tabular}


Tsany et al./JIITA Vol.1 Issue 2 (2017) 18-26 


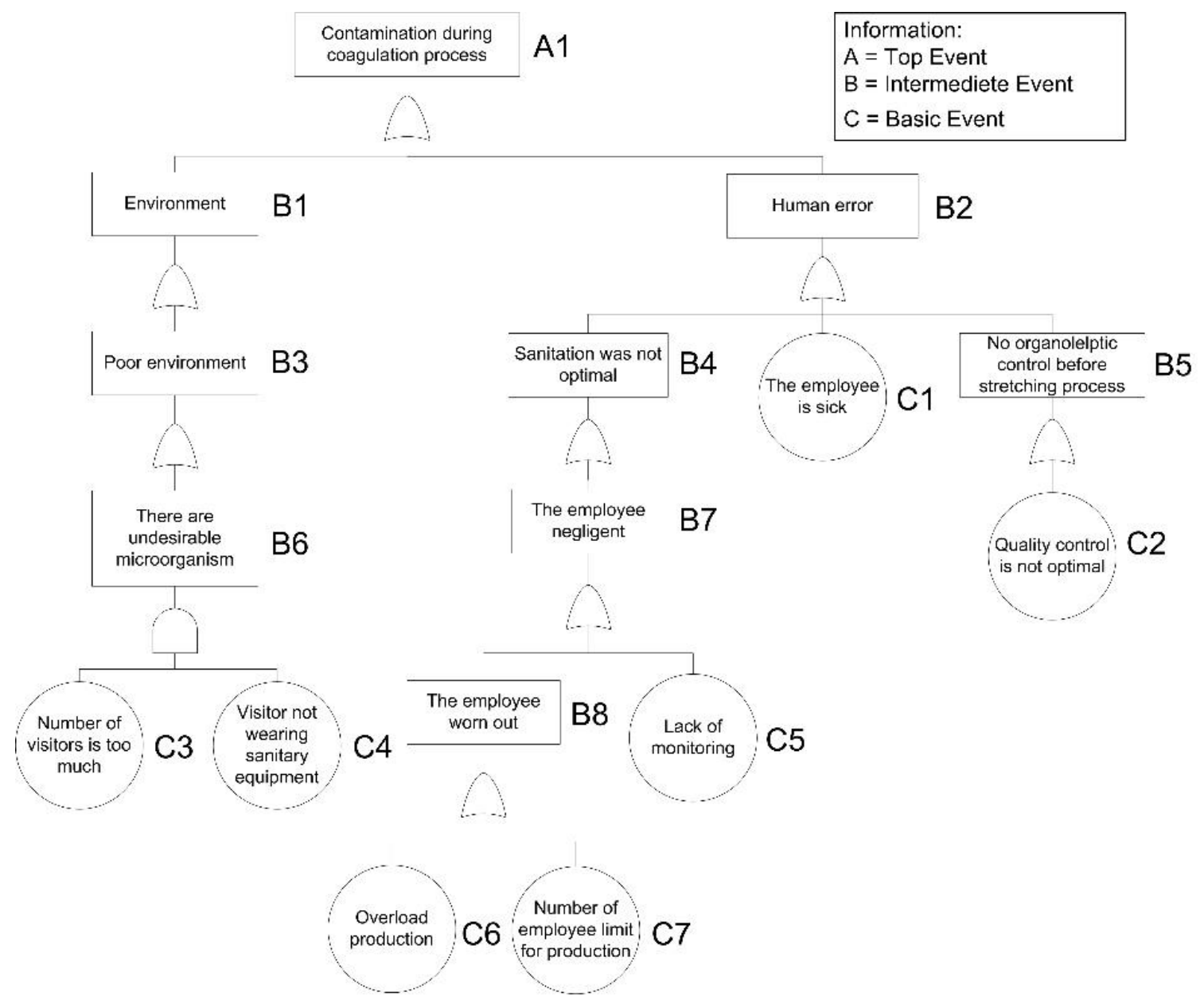

Figure 1 Fault Tree Diagram of Contamination during Curd Clotting Process

Based on the qualitative and quantitative analyses that were done, the minimum cut sets and probabilities of each

basic event were revealed. The probability calculations of each intermediate event have been made (Table 5 ).

Table 5 Probability Score Risk

\begin{tabular}{lc}
\hline \multicolumn{1}{c}{ Event } & Probability \\
\hline Contamination during clotting process & 0.095 \\
\hline Low-quality fresh milk & 0.005 \\
\hline Severe damage of stretcher machine & 0.005 \\
\hline Overly acidic cheese product & 0.005 \\
\hline
\end{tabular}

Table 5 indicated that the probability with the highest value was the probability contamination risk during the curd clotting process showing 0.095. It could be explained that the contamination during the curd clotting process was a highly possible risk in the future. Although the other three risks had low probability values, the impact of those risks also had an effect on the production process activity. Boolean algebra equations and quantitative analysis, the risk during the production of mozzarella cheese had 6 single 
minimum cut sets and 2 double minimum cut sets with a probability value of 0.110 .

If the value of probability is $>0$ and $<1$, then a probability value approaching 1 means that an undesired event has a greater chance to occur and vice versa; if the probability value approaches 0 , the chance of undesirable event is unlikely to occur [14]. Based on these calculations, the risk probability during the production of mozzarella cheese was 0.110 or the risk was $11 \%$. However, the probability value of $11 \%$ was intended if all risk occurred at the same time. Meanwhile, the FTA chart illustrated that the risks were separated by the GATE OR symbol, indicating that the risks that occurred during the production of mozzarella cheese did not occur simultaneously but only one or some of the risks. Therefore, the risk probability value occurring in the process of producing mozzarella cheese could be lower than $11 \%$.

\section{Recommendations for Improvement}

Based on the analysis and discussion, there are some recommendations for improvement which can be used to minimize the occurrence of risk during the process of mozzarella cheese production.

\section{Devising Sanitation Standard Operating Procedure (SSOP)}

Sanitation procedure carried out by $\mathrm{CV}$ XYZ was still based on the head's instructions. Thus it is feared that the procedure will cause contamination since it has not been adjusted to the applicable standards. The new version of SSOP should cover building sanitation, machinery and equipment sanitation, and employee sanitation. Also, SSOP should also have eight aspects: water safety of production process, surface hygiene conditions in contact with foodstuffs, prevention of cross contamination from non-sanitary objects, worker hygiene, prevention or protection from adulteration, proper labeling and storage, health control for employees, pest control [15]. With the existence of SSOP, CV $\mathrm{XYZ}$ already has a guidance of sanitation activities based on the existing standards. So the provision of sanitation equipment to the visitor will be included in the company's sanitation standards. Sanitation equipments that needs to be given include mask and hair mask / hairnet.

\section{Devising Standard Operating Procedure (SOP)}

The procedure of production process implemented by CV XYZ was still based on the head's instructions. Thus it is feared that the procedure will cause contamination since it has not been adjusted to the applicable standards. The new version of SOP should cover a set of standard operational procedure which is used as a guideline for the company to ensure that each step of the production process runs effectively and consistently, and complies with the standard and system [16]. There is a good change in the company after applying SOP [17]. The SOP that needs to be devised by CV XYZ can cover raw material handling activities, production and distribution, large number of product order, and company visit. Currently, $\mathrm{CV} \mathrm{XYZ}$ is in the process of preparing a written SOP tailored to the company's condition.

\section{Communication Improvement}

Good communication with consumers can produce a production schedule that suits the needs of demand. Communication can be said to be effective if the established communication meets the good qualities of openness, supportive attitude, positive attitude, empathy and equality [18]. Therefore, CV XYZ needs to be more open about the future plan of production schedule. It is used to prevent loss for consumers who will order products in large quantity.

\section{Counseling, Mentoring, Coaching (CMC) Application}

The head of the company can perform CMC for employees informally so that he or she can understand the factors causing negligence and monitor it indirectly. Coaching is for employees who have poor performance on skills and knowledge of tasks performed. Then, mentoring is for employees who already have good performance. It is done by monitoring and 
directing the implementation of the task concerned. Lastly, counseling is for employees who have personal problems which affect their performances.

\section{Medical Checkup from Company}

Medical checkup is the right of every worker; it is the obligation of the company. Medical checkup consist of pre-employment health checkup, periodic health checkup, and specific medical checkup.

\section{Employing Quality Control at Each Step of Production Process}

The quality control applied by CV XYZ was not optimal because the measurement of the cheese dough acidity level during the production process was only available during the stretching process. The quality control performed can be organoleptic control. If the organoleptic control is applied before the stretching step, so curd contamination can be detected more quickly.

\section{Conducting Preventive Treatment for Stretcher Machine}

Some preventive actions such as performing stretcher machine maintenance every month and regular checking can be done by $\mathrm{CV}$ XYZ. A low preventive maintenance is enough for each production machine. Meanwhile, monthly preventive maintenance is done by examining the inside part of the machine. Power failure is caused by power outage from State Electricity Company (PLN) and absence of generators in the company. The first thing that can be done by CV XYZ is identifying the electricity needs in order to meet the needs of the production process. Furthermore, the company can identify the availability of the generator and needed capacity. If the cost of purchasing a generator is too high, then the company can look for an alternative such as generator rentals.

\section{CONCLUSIONS}

There were 11 risks from 8 steps of production process including contamination from sanitary materials, contamination during milk flowing from tube to cheese vat, low-quality milk, the desired temperature was not reached, curd clotting was not maximal, contamination during clotting process, the resulting curd texture was too hard, contaminants entry during mixing process, severe damage of stretcher machine, overly acidic cheese product, and inefficiency packaging.

Analysis of FMEA method indicated risk critical value using RPN value compared with critical value. Critical risks during the process of mozzarella cheese production were contamination during curd clotting process, low-quality milk, severe damage of stretcher machine, overly acidic cheese product and contamination during milk flowing from tube to cheese vat.

The risk of contamination during the curd clotting process was caused by some factors such as too many visitors which were not equipped with sanitary equipment lack of supervision, overload production process or limited number of employees, sick employees, and not optimal quality test. The risk of low-quality milk was caused by supplier error. The risk of a severe damage of stretcher machine was caused by undetectable engine damage. The risk of cheese having an overly acidic taste was caused by power outages. Then, the risk of contamination during milk flowing from the tube to the cheese vat was caused by the open tube state during the milk transfer process. Thus it allowed contaminants or unwanted microorganisms entering the tube.

The recommendations for improvement that can be proposed are to devise Standard Operating Procedure (SOP) and Sanitation Standard Operating Procedure (SSOP) based on company's condition and it should be implemented properly. Improving communication with suppliers is also important so that the company will always get high-quality raw materials.

\section{REFERENCES}

[1] Herawati, H. Peluang Pemanfaatan Tapioka Termodifikasi Sebagai Fat Replacer pada Keju Rendah Lemak. Seminar Nasional Teknologi Peternakan dan Veteriner, 2011, BBPPPP, Bogor 
[2] Fox, P.F, Guinee T.P, Cogan T.M, McSweeney P.L.H. Fundamentals of Cheese Science. Aspen Publisher Inc. Maryland. 2000.

[3] Nur, SN., Saloko, S dan Kisworo, D. Kajian Mutu dan Daya Simpan Keju Mozzarella Probiotik dari Susu Kerbau. Jurnal Ilmu danTeknologi Pangan 1(1): 24-32. 2015.

[4] Mijan, M. A, Haque, M. A, Habib, M. A and Wadud, M.A. Evaluation of Quality of Mozzarella Cheese. Bangladesh Veteranian 27: 36-42

[5] Purwadi dan Prasetyo, WY. Pengaruh Penggunaan Bahan Pengawet Terhadap Kualitas Mikrobiologis Keju Mozzarella Yang Disimpan Pada Suhu Refrigerator. Jurnal Ilmu dan Teknologi Hasil Ternak 6(2): 37-40. 2011.

[6] Rohmatussolihat, Sari, N. M, Lisdiyanti, P, Widyastuti, Y dan Sukara, E. Pemanfaatan Milk Clotting Enzyme dari Lactobacillus casei D11 untuk Pembuatan Keju Mozzarella. J. Teknol. Dan Industri Pangan 26 (1): 63-71. 2012.

[7] Suradi, K. Pengendalian Zoonosis Melalui Management dan Penanganan Bahan Pangan Hasil Ternak. Jakarta. 2012.

[8] Jorgensen, H.J., T. Mork, H.R. Hogasen and L.M Rorvik. Enterotoxicgenic Staphylococcus aureus in Bulk Milk in Norway. J. Appl. Microbiol (99): 158166. 2005.

[9] Djaafar, T dan Rahayu, S. Cemaran Mikroba pada Produk Pertanian, Penyakit yang Ditimbulkan dan Pencegahannya. Jurnal Litbang Pertanian 26 (2): 67-75. 2007.

[10] Putra,M. N. M, Tama, P. I dan Darmawan, Z. Analisis Penyebab Defect Kapal Motor (KM) Pagerungan Pada Bagian Hull Construction (HC) dengan Metode Failure Mode Effect Analysis (FMEA) dan Fault Tree Analysis (FTA). Jurnal Rekayasa dan Manajemen Sistem Industri 3 (2): 291-300. 2015.
[11]Huang, H. Z, Tong, X dan Zuo, J. M. Posbist Fault Tree Analysis of Coherent Systems. J. Reliability Engineering and System Safety (84): 141-148. 2004.

[12] Chiozza, M. L and Ponzetti, C. FMEA: A Model for Reducing Medical Errors. J. Clinica Chimica Acta 404: 75-78. 2009.

[13]Wahyunegara, W. H, Alkaff, A dan Gamayanti, N. Analisis Keandalan Pada Bolier PLTU dengan Menggunakan Metode Failure Mode Effect Analysis (FMEA). Jurnal Teknik POMITS 1(1): 16. 2013.

[14] Addawiyah, A. S dan Windraswara, R. Pengembangan Risk Assesment Dalam Evaluasi Manajemen Penanggulangan Kebakaran Melalui Fault Tree Analysis. UNNES. Journal of Public Health 5 (1): 36-47. 2016.

[15]Dewanti, R., dan Hariyadi. Hand Out Metode Inspeksi dan Sanitation Standard Operating Procedures (SSOP). Departemen Teknologi Pangan dan Gizi, Fakultas Teknologi Pertanian. Institut Pertanian Bogor, Bogor. 2005.

[16]Tambunan, R. M. Standard Operating Procedure (SOP) Edisi 2. Maeistas Publishing. Jakarta. 2013.

[17] Prasanna, K. Standard Operating Procedure for Standalone Hotels. Research Journal of Management Sciences 1(1):1-9. 2013.

[18] Yanti, D. N. P. Kualitas Komunikasi Pelayanan Customer Service di PT Indosat, TBK Balikpapan. Ejournal Ilmu Komunikasi 1(2):39-54. 2013. 